Jurnal Keperawatan Silampari

Volume 2, Nomor 1, Desember 2018

e-ISSN: 2581-1975

p-ISSN: 2597-7482

DOI: https://doi.org/10.31539/jks.v2i1.311

\title{
HUBUNGAN ANTARA RELIABILITY DAN RESPONSIVENESS DENGAN LOYALITAS PASIEN DI RUANG RAWAT INAP
}

\author{
Liza Wati \\ Program Studi Ners, STIKES Hang Tuah Tanjung Pinang \\ Liza_chintin@yahoo.com
}

\begin{abstract}
ABSTRAK
Tujuan penelitian untuk mengetahui hubungan reliability dan responsiveness keperawatan dengan loyalitas pasien diruang rawat inap RSUD Kota Tanjungpinang. Desain penelitian dengan pendekatan studi korelasional. Hasil penelitian diketahui bahwa lebih separuh responden berasal dari kelompok umur dewasa awal yaitu sebanyak 38 orang $(57,6 \%)$, jenis kelamin perempuan $(51,5 \%)$, berpendidikan tinggi $(50 \%)$, dan bekerja $(77,3 \%)$. Berdasarkan jarak tempat tinggal responden didapatkan lebih separuh responden tinggal jauh dari rumah sakit $(57,6 \%)$, pada umumnya responden menggunakan asuransi $(83,3 \%)$. Berdasarkan pengalaman rawatan diketahui bahwa lebih separuh pasien belum pernah dirawat di RSUD Kota Tanjung Pinang (57,6 $\%)$. Hasil penelitian menunjukkan persepsi reliability $(p=0,008)$, dan persepsi responsiveness $(p=0,002)$. Simpulan, terdapat korelasi secara signifikan dengan loyalitas pasien, kekuatan hubungan cukup dan arah positif. Variabel yang paling dominan adalan responsiveness.
\end{abstract}

Kata Kunci: Loyalitas Pasien, Pelayanan Keperawatan, Reliability, Responsiveness

\begin{abstract}
The purpose of this study was to determine the relationship of reliability and responsiveness of nursing with patient loyalty in the inpatient room of Tanjungpinang City Hospital. Research design with a correlational study approach. The results showed that more than half of the respondents came from the early adult age group of 38 people (57.6\%), female sex (51.5\%), highly educated (50\%), and working (77.3\%). Based on the distance of the respondent's residence, it is found that more than half of the respondents live far from the hospital (57.6\%), in general respondents use insurance (83.3\%). Based on treatment experience, it is known that more than half of patients have never been treated at Tanjungpinang City Hospital (57.6\%). The results showed the perception of reliability $(p=0.008)$, and perception of responsiveness $(p=0.002)$. Conclusion, there is a significant correlation with patient loyalty, strength of relationship and positive direction. The most dominant variable is responsiveness.
\end{abstract}

Keywords: Patient Loyalty, Nursing Services, Reliability, Responsiveness 


\section{PENDAHULUAN}

Menurut WHO (2010) rumah sakit merupakan suatu tempat yang menyediakan produk berupa pelayanan jasa terutama jasa kesehatan mulai dari preventif dampai kuratif (Ahira, 2012). Investasi pada rumah sakit dalam beberapa tahun terakhir ini banyak diminati. Pertumbuhan rumah sakit sejak tahun 2008-2010 cenderung meningkat dengan rata-rata pertumbuhan per tahun sekitar 1,14\%.

Pertumbuhan dan perubahan eksternal rumah sakit meningkatkan persaingan dengan memberikan pelayanan berkualitas. Adanya perubahan persepsi masyarakat tentang kesehatan, meningkatkan pengetahuan tentang penyakit dan pengobatannya menjadikan tingginya kebutuhan terhadap kesehatan. Tingginya kualitas pelayanan dan pengobatan dirumah sakit luar negeri menjadikan masyarakat lebih tertarik untuk berobat keluar negeri. Tuntutan inilah yang mendorong manajemen rumah sakit untuk meningkatkan kualitas pelayanannya. Tuntutan masyarakat terhadap kualitas pelayanan keperawatan dirasakan sebagai suatu fenomena yang harus direspon oleh perawat (Nursalam, 2014).

Masyarakat yang kritis dalam mencari pelayanan kesehatan mereka tidak hanya mencari kesembuhan atau kesehatan yang merupakan core product dari rumah sakit, tetapi juga kenyamanan dan kemudahan sebagai atribut produk dalam berbagai bentuk seperti proses pendaftaran yang cepat termasuk kemudahan dalam cara pembayaran, perawat dan staf rumah sakit yang cepat tanggap terhadap kebutuhan mereka, mendapatkan informasi yang jelas atas pertanyaan mereka, dan sebagainya. Tuntutan atau harapan dari calon pasien inilah yang mendorong manajemen rumah sakit untuk meningkatkan kualitas pelayanannya sehingga pasien puas dan loyal terhadap produk jasa yang telah diberikan (Rahmani, 2018).

Ada dua pendekatan dasar loyalitas yaitu yang didasari oleh sikap dan perilaku. Pendekatan loyalitas didasari sikap adalah adanya komitmen atau ikatan emosional terhadap suatu perusahaan sedangkan pendekatan loyalitas yang didasari perilaku adalah dibuktikan oleh konsistensi pelanggan dalam pembelian berulang-ulang. Ada 5 (lima) dimensi loyalitas sebagai indikator pengukuran loyalitas yaitu kepercayaan, komitmen psikologi, perubahan biaya, perilaku publishing dan kerjasama. Jadi kelangsungan hidup rumah sakit akan dipengaruhi oleh pasien yang loyal, sehingga mempertahankan pasien menjadi hal yang paling penting (Kotler, Kettler, 2016)

Menurut Lele dan Sheth, upaya untuk menarik pelanggan yang baru rata-rata perusahaan menghabiskan waktu enam kali lebih banyak daripada waktu yang dipakainya untuk mempertahankan pelanggan lama. Padahal dalam sebagian besar kasus, loyalitas pelanggan mempunyai nilai 10 kali lebih besar daripada uang yang dibelanjakannya dalam satu kali pembelian untuk mendapatkan pelanggan baru diperlukan enam kali lipat biaya yang dibutuhkan dibandingkan dengan mempertahankan pelanggan lama (Hasan, 2008) . Kemudian menurut Kotler, Keller (2016) banyak perusahaan kehilangan $25 \%$ langganan mereka setiap tahun, dengan perkiraan biaya mencapai \$2 hingga \$4 miliar dan mengakuisisi pelanggan baru dapat menelan biaya lima kali lipat lebih besar dibandingkan memuaskan dan mempertahankan pelanggan lama.

Bloomer menyatakan usaha yang dilakukan untuk mempertahankan para pelanggan salah satunya adalah meningkatkan kualitas layanan perusahaan. Menurut Leboeuf, penurunan jumlah kunjungan pelanggan lama disebabkan; 3\% karena pindah tempat tinggal, 5\% karena menemukan persahabatan baru di perusahaan lain, 9\% karena bujukan pesaing, $14 \%$ karena merasa tidak puas, dan $68 \%$ karena sikap yang tidak perhatian yang diperlihatkan oleh pemilik, manajer atau petugas (Kotler, Keller, 2016). Kualitas merupakan perbandingan persepsi dengan ekspektasi pelanggan terhadap suatu 
produk. Parasuraman, Zeithmal dan Berry dalam Lupiyoadi (2013) menyimpulkan terdapat lima dimensi kualitas pelayanan yang disebut dengan SERVQUAL yaitu ; 1) Bukti fisik (tangible), 2) Keandalan (reliability), 3) Daya tanggap (responsiveness), 4) Jaminan (assurance), 5) Empati (emphaty).

Berdasarkan penelitian Jane et al, (2011) didapatkan bahwa keandalan dan empati mempengaruhi niat perilaku pasien. Penelitian Baroroh (2010) tentang hubungan antara persepsi terhadap kualitas pelayanan dancitra rumah sakit dengan loyalitas pasien di rumah sakit Roemani Muhammadiyah Semarang juga didapatkan persepsi kualitas pelayanan memiliki hubungan yang paling kuat dengan loyalitas. Jadi kualitas memiliki hubungan yang erat dengan loyalitas pasien, dimana kualitas memberikan dorongan kepada pasien untuk menjalin ikatan hubungan yang lebih kuat dengan rumah sakit.

Pada saat ini semakinbaiknya tingkat sosial ekonomi dan semakin tingginya tingkat pendidikan masyarakat, perkembangan pola penyakit, perkembangan teknologi kedokteran dan kesehatan serta perkembangan harapan masyarakat terhadap pelayanan rumah sakit maka semakin kritis pula pasien menilai kualitas pelayanan yang diperolehnyaapakah sesuai dengan harapan mereka, dibandingkan dengan nilai rupiah yang dikeluarkan. Fenomena berdasarkan Medical Excellence Japan Seminar: Indonesia- Japan Medical Collaboration menyebutkan, ada 600.000 warga Indonesia berobat ke luar negeri pada 2012. Biaya yang mereka keluarkan mencapai 1,4 miliar dollar Amerika Serikat atau setara Rp I3,5 triliun. Jumlah ini menunjukkan peningkatan berarti dibandingkan dengan tahun 2006. Saat itu ada 315.000 orang berobat ke luar negeri dengan total pembelanjaan mencapai 500 juta dollarAS (setara Rp 4,8 triliun dengan nilai tukar saat ini). Singapura dan Malaysia masih menjadi tujuan utama turis kesehatan Indonesia (M. Zid, 2013).

Pada tahun 2010 pasien Indonesia yang berobat di sejumlah rumah sakit Parkway Health Singapura mencapai 60 persen dari total pasien asing. Jumlah pasien asing di grup rumah sakit swasta ini 30 persen dari jumlah total pasien yang dilayani sebagian besar atau hampir $70 \%$ (dua pertiga dari total pasien) orang Indonesia yang secara finansial mampu. Sebanyak $60 \%$ persen di antaranya adalah etnis Tionghoa, yang berusia 31-50 tahun. Hal ini disebabkankan minimnya komunikasi efektif antara tenaga kesehatan atau managemen di rumah sakit dengan pasien (M. Zid, 2013).

Sejumlah negara lain kini juga mulai melirik calon pasien dari Indonesia seperti Thailand, China, India, atau Jepang. Pasien asing berasal dari sejumlah negara termasuk Indonesia.Selain berobat atas inisiatif sendiri, sebagian pasien dirujuk dokter di Indonesia.Provinsi Kepulauan Riau berbatasan dengan negara tetangga Singapura dan Malaysia dimana merupakan kawasan Segitiga Pengembangan SIJORI (Singapura, Johor, dan Riau). Adanya trend masyarakat untuk mencari pengobatan ke luar negeri didukung transportasi antar pulau cukup lancar merupakan ancaman bagi rumah sakit yang ada di Kepulauan Riau untuk mempertahankan pasiennya (M.Zid, 2013).

Rumah Sakit Umum Daerah (RSUD) Kota Tanjungpinang adalah salah satu rumah sakit pemerintah di Kepulauan Riau dan sudah menerapkan sistem PPK-BLUD sejak tahun 2010 serta menjadi rujukan di daerah Tanjungpinang dan sekitarnya. Adapun visinya yaitu menjadi rumah sakit unggulan di bidang pelayanan penyakit dalam dengan menerapkan patient safety pada Tahun 2015. Agar Visi Rumah RSUD dapat tercapai secara efektif dan efisien maka dalam melaksanakan misinya, RSUD membuat suatu perencanaan strategik yang berorientasi kepada pemenuhan kebutuhan dan keinginan masyarakat (customer), peningkatan efisiensi, efektifitas dan produktifitas serta disesuaikan dengan perkembangan dan kemampuan daerah. Salah 
satu strategi RSUD Kota Tanjungpinang adalah meningkatkan jumlah dan mutu pelayanan pada Ruang Perawatan.

Strategi rumah sakit untuk meningkatkan jumlah dan mutu pelayanan pada ruang perawatan perlu ditingkatkan lagi untuk tahun 2014 karena berdasarkan laporan rawat jalan RSUD Kota Tanjungpinang Tahun 2012 terjadi penurunan kunjungan terdiri dari; penurunan kunjungan pasien baru sebesar 6\%, dan penurunan pasien lama sebesar $19 \%$, sedangkan pada tahun 2013 terjadi peningkatan kunjungan sebesar 7,2\%. Peningkatan terutama pada pasien kunjungan ulang sebesar 28,6\%, sedangkan pasien baru berkurang sebesar 27,9\%. Berdasarkan kinerja rawat inapdari tahun 2008 - 2013 yaitu BOR ratarata $66,5 \%$ (cendrung menurun) dan belum sesuai dengan standar nasional yaitu 70 - 80 $\%$, rata-rata lama rawat seorang pasien ALOS rata-rata 4,168 (6-9), tempat tidur tidak terisi (TOI) rata-rata 3,736 (1-3), dan NDR rata-rata 20,63 (41-65).

Masih kurangnya kualitas pelayanan di ruang rawat inap juga bisa dilihat dari Bed Ocupation Rate (BOR) terbesar dari tahun 2013 adalah ruang S.VIP sebesar 58,77 \%, ruang VIP sebesar 81,87\%, kemudian Kelas-1 sebesar 66,81\%, Kelas-2 sebesar 43,63\% serta Kelas-3 sebesar $71,99 \%$. Dengan besarnya minat masyarakat terhadap pelayanan di ruang kelas VIP sementara jumlah tempat tidur di ruang VIP sangat terbatas, maka perlu dianalisis tentang bagaimana kualitas pelayanan di ruang rawat inap sehingga rumah sakit bisa membuat perencanaan strategis untuk meningkatkan kualitas pelayanan khususnya di ruang kelas $1-3$.

Kecendrungan penurunan BOR di RSUD Kota Tanjungpinang dari tahun 20092013 juga diikuti dengan penurunan kinerja pelayanan kesehatan untuk tahun 2012 sebagai-berikut; 1) Pasien pulang sembuh menurun sebesar $6,8 \%, 2$ ) pasien pindah RS /dirujuk sebanyak 910 orang, meningkat sebesar 0,6\% dari tahun sebelumnya. Pada tahun 2013 juga terjadi penurunan kinerja sebagai-berikut; 1) Pasien pulang sembuh menurun sebesar $7,1 \%$, 2) Pasien yang pindah atau dirujuk ke Rumah Sakit lain sebanyak 833 orang pasien. Penurunan kinerja ini diperkirakan karena beberapa hal seperti dioperasikannya RSU Propinsi Kepulauan Riau di KM.8 Tanjungpinang tahun 2012, adanya strategi RSAL Dr. Midiyato.S mulai meningkatkan kualitas pelayanan kesehatan dengan pembangunan ruangan trauma center dan akan menaikkan status RS menjadi Tipe B dimana RSAL ini berada tepat didepan RSUD Kota Tanjungpinang, serta adanya trend masyarakat Kepulauan Riau untuk berobat keluar negeri.

Berdasarkan laporan tahunan RSUD Kota Tanjungpinang tahun 2013 penurunan kinerja juga dipengaruhi adanya kerusakan peralatan penunjang kesehatan seperti peralatan rehabilitasi medik dimana alat dalam keadaan rusak dan kurang lengkap, diruang radiologi tidak ada dokter spesialis radiologi, alat banyak yang rusak terutama CT Scan, dan belum ada perawatan secara berkala. Selain itu adanya kerusakan prasarana gedung yang perlu diperbaiki yang sangat berpengaruh terhadap penurunan cakupan pelayanan seperti sarana gedung ruang ICU, kamar operasi, ruang rawat inap, rawat jalan, instalasi gizi, laundry, radiologi, laboratorium dan IGD yang dinilai dalam keadaan kurang baik. Sedangkan untuk gudang farmasi dan rumah karyawan dalam keadaan rusak berat.

Berdasarkan kinerja mutu pelayanan keperawatan klinik tahun 2013 menurut Standar Pelayanan Minimum (SPM) diruang rawat inap yaitu pemberian pelayanan diruang rawat inap adalah dokter spesialis dan perawat dengan pendidikan minimal adalah D3 Keperawatan, penanggungjawab pasien adalah dokter, ketersediaan pelayanan rawat inap yaitu ruang anak, penyakit dalam, kebidanan, bedah, dan ICU. Jam visite dokter setiap hari kerja, kejadian infeksi luka operasi, infeksi nasokomial, 
dan kejadian pasien jatuh $0 \%$. Angka infeksi jarum infus sebanyak 2,62\% $(\leq 1,5 \%)$, angka infeksi transfusi sebanyak 0,62 \% ( $\leq 0,01 \%)$, angka kematian bayi $<2000$ gr sebanyak $14,3 \%(100 \%)$, waktu tunggu operasi > 24 jam sebanyak 2,09\%, meninggal karena sepsis sebanyak $0,64 \%(\leq 0,2 \%)$, compliance rekam medic sebanyak $0,92 \%$ $(100 \%)$, kepuasan pasien terhadap mutu pelayanan rawat inap adalah $80 \%(\geq 90 \%)$.

Berdasarkan hasil penilaian persepsi kepuasan klien / keluarga terhadap mutu pelayanan asuhan keperawatann di RSUD Kota Tanjungpinang tahun 2013 didapatkan kepuasan tertinggi diruangan ICU (90\%) dan terendah diruang anggrek (78\%). Berdasarkan survey awal oleh peneliti terhadap 15 orang pasien didapatkan sebanyak 60 $\%$ mengatakan kurang puas dengan fasilitas ruang rawat seperti kelengkapan fasilitas dan kebersihan ruangan. Sebanyak 46,7 \% mengatakan kurang puas dengan informasi yang diberikan perawat tentang tata tertib, administrasi, tindakan keperawatan dan halhal yang harus dipatuhi dalam perawatan pasien.

Berdasarkan hasil obervasi tindakan keperawatan sesuai standar operasional prosedur di RSUD Kota Tanjungpinang tahun 2013 didapatkan dalam pemberian oksigen $95,85 \%$, pemasangan infus $95,84 \%$, memberikan tranfusi $96,52 \%$, clisma $83,48 \%$, memandikan pasien di tempat tidur $92,23 \%$, mengganti alat tenun $86,62 \%$, mengukur suhu badan 77,94 \%, mengitung nadi dan pernafasan 98,21 \%, mengganti balutan luka 87,95 \%, mengukur tekanan darah $100 \%$, memberikan obat melalui mulut $100 \%$ dan memberikan injeksi 95,01\%. Berdasarkan hasil evaluasi rentang kendali kepatuhan perawat dalam penerapan SAK diruang rawat inap RSUD Kota Tanjungpinang tahun 2013 didapatkan rata-rata 89,26 \% (Laporan RSUD Kota Tanjungpinang, 2013)

Adapun tujuan penelitian ini adalah 1) diketahui distribusi frekuensi pasien rawat inap, 2) diketahui hubungan antara reliability dan responsiveness dengan loyalitas pasien di ruang rawat inap RSUD Kota Tanjungpinang.

\section{METODE PENELITIAN}

Rabcangan dalam penelitian ini menggunakan rancangan penelitian korelasional. Penelitian ini bertujuan untuk mengetahui hubungan antara persepsi kualitas pelayanan keperawatan dan dimensi kualitas pelayanan keperawatan dengan loyalitas pasien diruang rawat inap RSUD Kota Tanjungpinang. Populasi dalam penelitian ini adalah pasien rawat inap RSUD Kota Tanjungpinang. Sampel 66 orang pasien dengan teknik proporsi random samplingVariabel dependen adalah loyalitas pasien total item kuesioner 19 dan variabel independen adalah kualitas pelayanan keperawatan dan sub variabel dimensi kualitas pelayanan keperawatan reliability, dan responsiveness total item 11 .

Data yang diambil dalam penelitian ini adalah data primer dan sekunder. Data primer didapatkan langsung dari responden dengan mengisi kuesioner. Data sekunder dari data studi kepustakaan, dari buku - buku literatur yang berkaitan dengan penelitian, dan dokumen - dokumen penting lainnya seperti laporan tahunan RS, profil RS, dan Medical Record di RSUD Kota Tanjungpinang. Langkah-langkah dalam prosedur penelitian ini adalah 1) permohonan data ke rumah sakit, 2) permohonan izin uji validitas dan penelitian, 3) Penjelasan penelitian, 4) Meminta persetujuan responden, 5) Pengisian kuesioner oleh responden, 6) Pengolahan data, dan 7) Analisis data. 


\section{HASIL PENELITIAN}

\section{Analisis Univariat}

Karakteristik Responden

Tabel. 1

Distribusi Frekuensi Karakteristik Responden (n=66)

\begin{tabular}{lcc}
\hline Karakteristik Responden & F & $\%$ \\
\hline Umur & 38 & 57,6 \\
$\quad$ Dewasa Awal ( 18-40 tahun) & 21 & 31,8 \\
$\quad$ Dewasa Madya ( 41-60 tahun) & 7 & 10,6 \\
$\quad$ Dewasa Akhir ( > 60 tahun ) & & \\
Jenis Kelamin & 32 & 48,5 \\
$\quad$ Laki - laki & 34 & 51,5 \\
$\quad$ Perempuan & & \\
Pendidikan & 33 & 50,0 \\
$\quad$ Rendah (SD - SMP ) & 33 & 50,0 \\
$\quad$ Tinggi ( SMA - PT ) & & \\
Pekerjaan & 51 & 77,3 \\
$\quad$ Bekerja & 15 & 22,7 \\
$\quad$ Tidak bekerja & & \\
Jarak tempat tinggal & 28 & 42,4 \\
$\quad$ Dekat (<5 KM ) & 38 & 57,6 \\
$\quad$ Jauh (> 5 KM ) & & \\
Sumber biaya pengobatan & 55 & 83,3 \\
$\quad$ Asuransi & 11 & 16,7 \\
$\quad$ Pribadi & 28 & 42,4 \\
Pengalaman rawatan & 38 & 57,6 \\
$\quad$ Pernah & & \\
$\quad$ Tidak pernah &
\end{tabular}

Berdasarkan tabel 1 dapat diketahui bahwa lebih separuh responden berasal dari kelompok umur dewasa awal yaitu sebanyak 38 orang $(57,6 \%)$, jenis kelamin perempuan $(51,5 \%)$, berpendidikan tinggi ( $50 \%)$, dan bekerja $(77,3 \%)$.

Berdasarkan jarak tempat tinggal responden didapatkan lebih separuh responden tinggal jauh dari rumah sakit $(57,6 \%)$, pada umumnya responden menggunakan asuransi $(83,3 \%)$. Berdasarkan pengalaman rawatan diketahui bahwa lebih separuh pasien belum pernah dirawat di RSUD Kota Tanjungpinang (57,6\%).

\section{Loyalitas Pasien}

Tabel. 2

Distribusi Frekuensi Loyalitas Pasien ( $\mathrm{n}=66$ )

\begin{tabular}{llcc}
\hline No & Kategori & F & $\%$ \\
\hline 1. & Loyal & 40 & 60.6 \\
2. & Kurang loyal & 26 & 39,4 \\
\hline & & 66 & 100
\end{tabular}


Berdasarkan tabel 2 Berdasarkan tabel didapatkan sebagian besar pasien yang cendrung loyal terhadap pelayanan keperawatan yaitu sebanyak 40 orang $(60,6 \%)$

\section{Kualitas Pelayanan Keperawatan dan Dimensi Kualitas Pelayanan Keperawatan}

Tabel. 3

Distribusi Frekuensi Responden Berdasarkan Persepsi Kualitas Pelayanan Keperawatan (n=66)

\begin{tabular}{lcc}
\hline \multicolumn{1}{c}{ Kategori } & F & Persentase \\
\hline Dimensi Reliability & 36 & \\
$\quad$ Baik & 30 & 54,5 \\
$\quad$ Kurang baik & & 45,5 \\
Dimensi Responsiveness & 33 & \\
$\quad$ Baik & 33 & 50,0 \\
Kurang baik & 50,0 \\
\hline
\end{tabular}

Berdasarkan tabel didapatkan persepsi responden terhadap dimensi reliability lebih separuh baik $(54,5 \%)$ dan persepsi dimensi responsiveness sebagian baik $(50,0 \%)$.

\section{Analisis Bivariat}

Tabel. 4

Hubungan Kualitas Pelayanan Keperawatan dengan Loyalitas Pasien (n=66)

\begin{tabular}{lccc}
\hline \multicolumn{1}{c}{ Variabel Independen } & $\mathrm{R}$ & $\mathrm{R}^{2}$ & $\mathrm{p}$ value \\
\hline Reliability & 0,323 & 10,4 & 0,008 \\
Responsivenes & 0,372 & 13,8 & 0,002 \\
\hline
\end{tabular}

Pada tabel 4 hasil analisis didapatkan untuk mengetahui hubungan dimensi reliability dengan loyalitas pasien diperoleh nilai $\mathrm{r}=0,323$ dengan $p$ value $=0,008<$ 0,05 . Kesimpulan adalah terdapat korelasi yang signifikan antara persepsi dimensi reliability dengan loyalitas pasien di RSUD Kota Tanjungpinang dengan kekuatanhubungan cukup kuat dan arah positif yang artinya semakin baik dimensi reliability maka semakin baik sikap loyalitas pasien.

Hasil analisis didapatkan untuk mengetahui hubungan dimensi responsiveness dengan loyalitas pasien diperoleh nilai $\mathrm{r}=0,372$ dengan $p$ value $=0,002<0,05$. Kesimpulan adalah terdapat korelasi yang signifikan antara persepsi dimensi responsiveness dengan loyalitas pasien di RSUD Kota Tanjungpinang dengan kekuatan hubungan cukup kuat dan arah positif yang artinya semakin baik dimensi responsiveness maka semakin baik sikap loyalitas pasien. 


\section{PEMBAHASAN}

\section{Karakteristik Responden}

Hasil penelitian dapat diketahui bahwa lebih separuh responden berasal dari kelompok umur dewasa awal yaitu sebanyak 38 orang $(57,6 \%)$, jenis kelamin perempuan $(51,5 \%)$, berpendidikan tinggi $(50 \%)$, dan bekerja $(77,3 \%)$. Berdasarkan jarak tempat tinggal responden didapatkan lebih separuh responden tinggal jauh dari rumah sakit (57,6\%), pada umumnya responden menggunakan asuransi (83,3\%). Berdasarkan pengalaman rawatan diketahui bahwa lebih separuh pasien belum pernah dirawat di RSUD Kota Tanjungpinang (57,6 \%).

Kotler, Keller (2016) menyatakan konsumsi dan selera seseorang dibentuk oleh jenis kelamin. Supriyanto, Ernawaty (2010) juga menyatakan ada perbedaan tertentu antara wanita dan laki-laki, misalnya dalam perbedaan kebutuhan, keinginan dan harapan. Kotler (2016) menambahkan, kelompok wanita biasanya menggunakan jasa atau produk pelayanan kesehatan lebih banyak dibandingkan dengan kelompok pria.

Kotler, Keller (2016) menyatakan konsumsi dan selera seseorang dibentuk oleh usia. Supriyanto, Ernawaty (2010) juga menyatakan kebutuhan, keinginan, dan harapan seseorang dipengaruhi umur pula. Kebutuhan terlihat jelas pada hal tertentu. Misalnya penyakit degeneratif banyak dijumpai pada kelompok umur di atas 50 tahun. Kotler (2016) menambahkan kebutuhan, keinginan dan harapan dapat terlihat berbeda pada masing-masing kelompok usia.

Kotler, Keller (2016) menyatakan pekerjaan juga mempengaruhi pola konsumsi, seseorang yang memiliki pekerjaan tertentu akan membeli kebutuhan yang sesuai dengan pekerjaannya. Kotler, Keller (2016) menyatakan pilihan produk sangat dipengaruhi oleh keadaan ekonomi; penghasilan yang dapat dibelanjakan, tabungan dan aset, dan sikap terhadap pengeluaran tabungan. Supriyanto, Ernawaty (2010) juga berpendapat serupa bahwa pendapatan secara jelas mempengaruhi penggunaan produk atau jasa pelayanan kesehatan dengan memberikan peluang dari kekayaan yang dimiliki. Bahkan, jenis jasa yang digunakan dapat bervariasi karena faktor pendapatan ini.

Kotler, Shalowitz, \& Stevens (2008) menyatakan bahwa pendidikan, terlepas dari pengetahuan mengenai kesehatan, juga merupakan faktor determinan yang penting yang mempengaruhi penggunaan pelayanan kesehatan. Laporan riskesdas nasional tahun 2013 menyebutkan waktu tempuh rumah tangga menuju fasilitas kesehatan di rumah sakit pemerintah tertinggi pada $16-30$ menit $(34,4 \%)$ dan terendah $>60$ menit $(18,5 \%)$. Pola ini hampir sama dengan waktu tempuh menuju rumah sakit swasta dimana tertinggi pada $16-30$ menit $(37,3 \%)$ dan terendah $>60$ menit $(12,4 \%)$. Sedangkan pada fasilitas kesehatan di puskesmas atau pustu, praktek dokter atau klinik, praktek bidan atau rumah bersalin, poskesdes atau poskestren, polindes dan posyandu terbanyak pada waktu tempuh $\leq 15$ menit.

Kotler (20016) menyatakan hal yang termasuk dalam kategori ini adalah status jaminan atau penanggung biaya. Survey nasional di Amerika Serikat tahun 2003 menunjukkan bahwa kondisi penyakit kronis lebih banyak ditemukan pada orang dewasa yang tidak memiliki asuransi dibandingkan yang berasuransi. Hasil Riskesdas Nasional tahun 2013 menyebutkan bahwa secara nasional, sumber utama pembiayaan yang digunakan oleh rumah tangga untuk rawat berobat adalah dari kantong sendiri (out of pocket) dengan persentase sebesar (74\%).

Selain faktor-faktor individu yang telah dikemukakan diatas, beberapa penelitian sebelumnya seperti Ulfa (2012) juga mengatakan bahwa usia, pendidikan, pekerjaan, 
jarak tempat tinggal dan penanggung biaya memiliki hubungan yang kuat dengan loyalitas pelanggan. Sedangkan Suhanura (2008) dalam penelitiannya mengenai loyalitas pelanggan, menambahkan faktor alasan memilih RS dan frekuensi kunjungan.

\section{Loyalitas pasien}

Hasil penelitian menunjukkan bahwa sebagian besar $(60,6 \%)$ responden mempunyai sikap loyal terhadap pelayanan keperawatan. Loyalitas pasien merupakan sikap pasien terhadap pihak rumah sakit yang diwujudkan dalam komitmen berkesinambungan dan kecenderungan untuk menggunakan rumah sakit secara konsisten berdasarkan pertimbangan faktor kognitif, afektif dan evaluatif (Sangadji, 2013). Penilaian sikap ini berdasarkan persepsi pasien terhadap pelayanan keperawatan yang telah diterimanya selama perawatan di ruang rawat inap RSUD Kota Tanjungpinang.

Griffin, J (2016) menyatakan pelanggan tumbuh menjadi pelanggan yang loyal secara bertahap. Proses itu dilalui dalam jangka waktu tertentu, dengan kasih sayang, dan dengan perhatian yang diberikan pada tiap-tiap tahap pertumbuhan. Setiap tahap memiliki kebutuhan khusus dengan mengenali setiap tahap danmemenuhi kebutuhan khusus tersebut, perusahaan mempunyai peluang yang lebih besar untuk mengubah pembeli menjadi pelanggan atau klien yang loyal.

Beberapa tahapan klasifikasi loyalitas seseorang terhadap produk atau jasa menurut Kotler (2016) yaitu : 1) Tersangka (suspect), 2) Calon pelanggan (Prospect), 3) Prospek yang diskualifikasi, 4) Pelanggan pertama kali (First Time Consumens), 5) Pelanggan berulang (Repeat Customer), 6) Klien (Client), 7) Keanggotaan (Members), 8) Penganjur (advocate)

Sikap loyal pasien ini ditentukan oleh adanya kepercayaan pasien terhadap pelayanan keperawatan, komitmen psikologis yang terbentuk selama mendapatkan perawatan, sikap pasien untuk bertahan terhadap pelayanan, sikap pasien untuk mau mempromosikan, merekomendasikan dan mendorong orang lain untuk menggunakan pelayanan keperawatan di rumah sakit RSUD Kota Tanjungpinang serta sikap pasien untuk mau bekerjasama dengan rumah sakit.

Menurut Tjiptono (2014) sesungguhnya pelanggan yang loyal sangatlah bernilai bagi perusahaan dan pada umumnya pesaing sulit untuk merebut mereka. Selain itu mereka juga bisa menjadi pengiklan perusahaan, artinya mereka dapat memberikan rekomendasi dan keuntungan yang sangat besar bagi perusahaan, karena mempengaruhi pola pembelian pelanggan dan rekomendasi gratis yang diberikan pelanggan kepada orang lain. Makin lama seorang pelanggan bertahan, makin besar laba yang diperoleh perusahaan karena melayani mereka (Setiawan, 2011).

Ada empat faktor yang mendasari pertumbuhan laba dari pelanggan yang loyal. Faktor-faktor tersebut adalah: 1) Laba yang diperoleh dari peningkatan pembelian, 2) Laba dari biaya operasi yang berkurang, 3) Laba dari referensi kepada pelanggan lain, 4) Laba dari harga yang tinggi. Pengalaman yang bersifat emosional dan kepuasan mendasari sikap yang cukup tinggi terhadap penawaran seseorang, maka selain sebagai pembeli ulang juga akan memberikan pujian. Merujuk hal tersebut pengalaman dan emosional yang baik merupakan suatu persepsi konsumen. Persepsi yang baik dapat meningkatkan loyalitas yang memiliki indikator pada pembelian ulang. Jadi loyalitas pelanggan akan dipengaruhi oleh adanya komitmen yang tinggi, kepercayaan dan pembelian ulang (Kotler, Keller, 2016). 


\section{Hubungan Dimensi Reliability dengan loyalitas pasien}

Hasil analisis didapatkan ada korelasi yang signifikan antara persepsi dimensi reliability dengan loyalitas pasien di RSUD Kota Tanjungpinang dengan kekuatan hubungan cukup dan arah positif yang artinya semakin baik dimensi reliability maka semakin baik sikap loyalitas pasien.

Reliability yaitu kemampuan perusahaan untuk memberikan pelayanan sesuai dengan yang dijanjikan secara akurat dan terpercaya. Kinerja harus sesuai dengan harapan pelanggan yang berarti ketepatan waktu, pelayanan yang sama untuk semua pelanggan tanpa kesalahan, sikap yang simpatik, dan dengan akurasi yang tinggi. Hal ini berarti perusahaan memberikan jasanya secara tepat semenjak saat pertama (right the first time). Selain itu juga berarti bahwa perusahaan yang bersangkutan memenuhi janjinya, misalnya menyampaikan jasanya sesuai dengan jadwal yang disepakati. Dalam unsur ini, rumah sakit dituntut untuk menyediakan jasa yang handal. Jasa jangan sampai mengalami kerusakan / kegagalan. Dengan kata lain jasa tersebut harus selalu baik. Para petugas rumah sakit juga harus jujur dalam menyelesaikan masalah sehingga pasien tidak merasa ditipu. Selain itu, rumah sakit harus tepat janji bila menjanjikan sesuatu kepada pasien. Sekali lagi perlu diperhatikan bahwa janji bukan sekedar janji, namun janji harus ditepati. Oleh karena itu, time schedule perlu disusun dengan teliti (Lupiyoadi, 2013).

Long, Green (1994) berpendapat bahwa perawatmemiliki konstribusi yang unik terhadapkepuasan pasien dan keluarganya. Hal sama dikemukakan Lovelock, Wright (2005) yang menyatakan perlu ada kesesuaian antara pelayanan yang diberikan dengan apa yang dibutuhkan dari waktu ke waktu (Hasan, 2014).

Dalam tatanan pelayanan kesehatan, perawat menjadi kunci keberhasilan dalam menyelenggarakan pelayanan kesehatan. Dari berbagai sumber menyatakan bahwa $40 \%$ tenaga yang ada dirumah sakit adalah tenaga keperawatan dan sebanyak $90 \%$ pelayanan yang ada dirumah sakit adalah pelayanan keperawatan. Pelayanan keperawatan yang berkualitas sesuai dengan keinginan pasien menyebabkan meningkatnya jumlah dan peran perawat pada tingkat layanan kesehatan tersebut (Asmuji, 2012). Jadi perkembangan zaman membawa dampak besar bagi profesi keperawatan. Tuntutan masyarakat atas pelayanan keperawatan yang semakin meningkat membuat perawat sebagai profesi yang mempunyai andil dan tanggungjawab yang besar dalam memberikan pelayanan berkualitas.

Menurut Sviokla. J dalam Lupiyoadi (2013) jika rumah sakit memfokuskan pada kualitas pelayanan maka akan mendapatkan dua keuntungan jangka panjang yaitu ekternal dan internal. Adapun keuntungan ekternal yang dimaksud dapat diimplikasikan dalam proses produksi jasa yaitu dimana kualitas pelayanan yang diberikan dapat menciptakan suatu persepsi dari pasien terhadap rumah sakit serta menghasilkan kepuasan dan loyalitas pasien. sedangkan keuntungan internal yaitu dapat membawa nilai positif internal rumah sakit dalam proses peningkatan pelayanan.

Berdasarkan hasil penilaian 5 item kuesioner didapatkan sebagian besar menilai baik. Sebagian besar ( 54,5\%) menilai item 1 baik disebabkan oleh masalah perawatan pasien mampu ditangani perawat dengan tepat dan professional. Pelayanan dipersepsikan subjektif oleh pasien sehingga pada saat penyampaian jasa, pemberi jasa berhadapan langsung dengan konsumen (front office), maka persepsi yang diberikan konsumen sangat berbeda-beda, karena persepsi bersifat subjektif dan sangattergantung dari kondisi keadaan yang dirasakannya pada saat melakukan kontaklayanan. Jadi bukan hanya perawat yang bisa dinilai tapi semua petugas yang melakukan kontak 
dengan pasien. Jika dilihat dari kemampuan perawat sesuai dengan kualifikasi perawat diruangan yang terdiri dari; 5 orang S-1 keperawatan Ners, 13 orang S1 Keperawatan, 3 orang D4 Keperawatan Gawat Darurat, 4 orang D4 keperawatan medik bedah, 133 orang D3 keperawatan, 3 orang D-3 keperawatan anestesi, dan 2 perawat SPK. Kemampuan tersebut ditambah dengan kegiatan yaitu sebanyak 174 pegawai pada tahun 2013, mengikuti pelatihan atau kursus singkat untuk meningkatkan pengetahuan dan keterampilan petugas. Sebanyak 96 orang $(55,2 \%)$ mengikuti pelatihan/seminar di luar daerah, dan 78 orang $(44,8 \%)$ mengikuti pelatihan/seminar di dalam daerah.

Penilaian item 2 sebagian besar $(43,9 \%)$ responden menilai baik karena informasi yang diberikan untuk kemudahan dan keselamatan pasien dalam perawatan. Salah satu dari 7 langkah menuju keselamatan pasien adalah menintegrasikan aktivitas pengelolaan resiko dengan mengembangkan sistem dan proses pengelolaan resiko, serta melakukan identifikasi dan asesmen hal yang potensial bermasalah. Misalnya penggunaan bed yang benar untuk menghindari pasien jatuh. Sebagian besar $(50,0 \%)$ menilai item 3 baik artinya perawat sudah mampu menjelaskan hal-hal yang harus dipatuhi pasien selama perawatan misalnya dari segi makanan, aktivitas fisik, perawatan diri, dll. Hal itu mengindikasikan bahwa pendidikan kesehatan kepada pasien sudah masuk kedalam perencanaan dan tindakan keperawatan (Nursalam, 2014).

Penilaian item 4 sebagian besar $(56,1 \%)$ responden menilai baik karena tingginya tanggung jawab perawat terhadap keselamatan pasien sehingga perawat dalam memberikan asuhan keperawatan selalu mengingatkan pasien hal-hal yang tidak boleh dilakukan pasien. Menurut Groner, Sorhin dalam Pohan. I (2012) 5 (lima) faktor utama yang mempengaruhi demand terhadap pelayanan kesehatan adalah: a.) Persepsi sakit, b.) Realisasi kebutuhan (harapan, kepercayaan, pengalaman sebelumnya, adat istiadat), c.) Kemampuan membayar, d.) Motivasi untuk memperoleh pelayanan kesehatan, e.) Lingkungan (tersedianya fasilitas pelayanan kesehatan). Perawat mengetahui bahwa program keselamatan pasien rumah sakit sangatlah penting dan merupakan peningkatan dari program mutu yang selama ini dilaksanakan secara konservatif. Salah satu dari tujuh langkah menuju keselamatan pasien adalah membangun kesadaran akan nilai keselamatan pasien.

Menurut Watzlawick, Bavelas \& Jackson (2011) menjelaskan ketika orang berinteraksi satu dengan yang lain, mereka mengirim pesan tertentu, sehubungan dengan proses interpersonal ini, ada tiga dimensi yang harus diperhatikan: komunikasi, pengambilan keputusan yang berorientasi pada pasien, dan perilaku interpersonal.

Persepsi akan berpengaruh pada perilaku pasien sebagai konsumen yang akhirnya berperngaruh pada keputusan membeli (Kotler, 2016). Persepsi yang positif akan mendorong pasien untuk mempercayakan kesehatannya pada rumah sakit tersebut. Persepsi pasien terhadap mutu pelayananakan menetukan perilaku pasien di dalam keputusan membeli produk jasa layanan kesehatan.

Penilaian item 5 sebagian besar $(45,5 \%)$ responden menilai baik karena perawat menyadari prioritas pelayanan keperawatan adalah keselamatan pasien. Pasien yang membutuhkan pertolongan perawat biasanya pasien yang parsial atau total care. Perawat harus segera datang saat pasien membutuhkan dan saat pasien merasa puas dengan pelayanan yang diberikan ini mengindikasikan pelayanan tersebut bermutu. Menurut Nursalam (2014) kepuasan terhadap jasa pelayanan mengacu pada beberapa faktor salah satunya ketepatan waktu. Kepuasan pasien adalah hal yang utama yang perlu diprioritaskan oleh rumah sakit agar dapat bertahan, bersaing dan mempertahankan pasiennya. 
Penelitian Triwardani (2017); Putri, Heru (2014) didapatkan hubungan antara komunikasi, kehandalan dan daya tanggap perawat dengan kepuasan pasien. senada dikemukakan Long, Green (1994) berpendapat bahwa perawat memiliki konstribusi yang unik terhadap kepuasan pasien dan keluarganya. Menurut peneliti reliability adalah kemampuan rumah sakit untuk memberikan pelayanan kesehatan sesuai dengan yang dijanjika secara akurat dan terpercaya.

Hal ini berarti rumah sakit memberikan pelayanan secara tepat semenjak pertama (right the first time) pasien masuk sampai pasien keluar dari rumah sakit. Selain itu juga harus memberikan pelayanan keperawatan seperti yang telah dijanjikan seperti disampaikan melalui visi menjadi rumah sakit unggulan di bidang pelayanan penyakit dalam dengan menerapkan patient safety pada tahun 2018 sedangkan misi pertama RSUD Kota Tanjungpinang yaitu memberikan pelayanan kesehatan bermutu yang sesuai dengan standar dan terjangkau oleh semua lapisan masyarakat dalam rangka meningkatkan derajat kesehatan masyarakat. Menurut Dever dalam Muninjaya (2012) faktor-faktor yang mempengaruhi pemanfaatan pelayanan kesehatan adalah sosial budaya, organisasi, faktor konsumen, proses pelayanan kesehatan.

Hal ini menunjukkan bahwa rumah sakit berjanji akan memberikan pelayanan terbaik untuk pasiennya. Kinerja rumah sakit juga harus sesuai dengan harapan pasien yang berarti ketepatan waktu, pelayanan yang sama untuk semua pelanggan tanpa kesalahan, sikap yang simpatik, dan dengan akurasi yang tinggi. Jika hal itu terpenuhi sesuai harapan pasien maka pelayanan yang diberikan bisa dikatakan berkualitas dan pasien yang merasakan selama dirawat akan membentuk perilaku loyal terhadap pelayanan keperawatan (Muninjaya, 2012).

Penyampaian pesan yang dilakukan oleh perawat terhadap pasien, akan lebih berhasil jika pasien dengan senang hati bersedia mengikuti beberapa informasi yang disampaikan oleh perawat sebagai komunikator, sejalan dengan penelitian Putri, Heru (2014) didapatkan faktor - faktor yang mempengaruhi komunikasi perawat dan pasien adalah segipengalaman, latar belakang budaya, sosial ekonomi, pendidikan.Jadi oleh sebab itu menurut peneliti pesan yang disampaikan perawat harus dapat diterima dengan baikdan dapat dimengerti dengan mudah oleh pasien. Karena itu diperlukan suatu bentuk komunikasi yang bukan sekadar sebagaikegiatan memberikan informasi belaka, namun harus berupa pemberian informasi yang mengandung nilai motivasi bagi pasien untuk dapat mengubah sikap, opini atau perilaku pasien melalui pendekatan komunikasi interpersonal.

Penelitian yang mendukung yaitu penelitian Ulfa (2012) tentang hubungan karakteristik, kualitas layanan dan hambatan pindah dengan loyalitas pasien didapatkan bahwa responden yang menilai dimensi reliability baik akan lebih loyal dibanding responden yang menilai dimensi reliability tidak baik di pelayanan rawat jalan Rumah Sakit Tugu Ibu. Hasil penelitian ini dapat terlihat dari mayoritas responden $(73,6 \%)$ yang menilai baik terhadap dimensi reliability juga menyatakan loyal terhadap pelayanan rawat jalan Rumah Sakit Tugu Ibu. Penelitian Suharno, hihab (2010) tentang pengaruh dimensi reliabilitas, dimensi tangibel dan dimensi empati terhadap loyalitas pasien di RS MRCCC Siloam Semanggi didapatkan dimensi reliabilitas berpengaruh positif dan signifikan terhadap loyalitas pasien rawat jalan.

Berdasarkan penelitian Supartiningsih (2017) didapatkan ada hubungan yang positif antara reliability kepuasan pasien untuk rawat jalan. Combs, dkk (2006) dalam penelitian mereka mengenai loyalitas pasien rawat jalan di 5 rumah sakit besar di 
Bangkok, juga mengindikasikan faktor doctor concern sebagai salah satu komponen dari dimensi reliability memiliki pengaruh kuat terhadap loyalitas pelanggan.

\section{Hubungan Dimensi Responsiveness dengan Loyalitas Pasien}

Hasil analisis didapatkan ada korelasi yang signifikan antara persepsi dimensi responsiveness dengan loyalitas pasien di RSUD Kota Tanjungpinang dengan kekuatan hubungan yang cukup kuat dan arah positif yang artinya semakin baik dimensi responsiveness maka semakin baik sikap loyalitas pasien.

Responsiveness yaitu suatu kemauan untuk membantu dan memberikan pelayanan yang cepat (responsif) dan tepat kepada pelanggan dengan penyampaian informasi yang jelas. Membiarkan konsumen menunggu tanpa adanya alasan yang jelas menyebabkan persepsi yang negatif dalam kualitas pelayanan. Ketanggapan merupakan keinginan para staf untuk membantu para konsumen dan memberikan pelayanan dengan tanggap (Nursalam, 2014).

Daya tanggap dapat berarti respon atau kesigapan karyawan dalam membantu pelanggan dan memberikan pelayanan yang cepat dan sigap, yang meliputi kesigapan karyawan dalam melayani pelanggan, kecepatan karyawan dalam menangani transaksi, dan penanganan. Unsur lain yang juga penting dalam elemen cepat tanggap ini adalah anggota perusahaan selalu siap membantu pelanggan.

Berdasarkan hasil penilaian 6 item kuesioner didapatkan sebagian besar responden menilai baik. Penilaian item 6 sebanyak $62,1 \%$ responden menilai baik disebabkan perawat memahami upaya penyembuhan dan pemulihan rasa sakitnya dan pasien mengharapkan pelayanan yang siap, cepat dan tanggap serta nyaman terhadap keluhan penyakitnya. Unsur lain yang juga penting dalam elemen cepat tanggap ini adalah perawat selalu siap membantu pasien kapan pun pasien membutuhkan. Masyarakat yang kritis dalam mencari pelayanan kesehatan mereka tidak hanya mencari kesembuhan atau kesehatan yang merupakan core product dari rumah sakit, tetapi juga kenyamanan sebagai atribut produk dalam berbagai bentuk seperti proses pendaftaran yang cepat termasuk kemudahan dalam cara pembayaran, perawat dan staf rumah sakit yang cepat tanggap terhadap kebutuhan mereka, mendapatkan informasi yang jelas atas pertanyaan mereka, dan sebagainya. Tuntutan atau harapan dari calon pasien inilah yang mendorong manajemen rumah sakit untuk meningkatkan kualitas pelayanannya sehingga pasien puas dan loyal terhadap produk jasa yang telah diberikan (Nursalam, 2014).

Penilaian item 7 sebagi besar $(60,6 \%)$ yang menilai baik disebabkan oleh perawat memahami jika membiarkan pasien menunggu tanpa adanya alasan yang jelas menyebabkan persepsi yang negatif dalam kualitas pelayanan. Ketanggapan merupakan keinginan para staf untuk membantu para konsumen dan memberikan pelayanan dengan tanggap. Berdasarkan hasil obervasi tindakan keperawatan sesuai standar operasional prosedur di RSUD Kota Tanjungpinang tahun 2013 didapatkan dalam pemberian oksigen 95,85\%, pemasangan infus 95,84\%, memberikan tranfusi 96,52\%, clisma $83,48 \%$, memandikan pasien di tempat tidur $92,23 \%$, mengganti alat tenun 86,62 \%, mengukur suhu badan 77,94 \%, mengitung nadi dan pernafasan 98,21\%, mengganti balutan luka 87,95 \%, mengukur tekanan darah $100 \%$, memberikan obat melalui mulut $100 \%$ dan memberikan injeksi 95,01\%. Berdasarkan hasil evaluasi rentang kendali kepatuhan perawat dalam penerapan SAK diruang rawat inap RSUD Kota Tanjungpinang tahun 2013 didapatkan rata-rata 89,26\%. 
Ada enam indikator utama kualitas pelayanan kesehatan dirumah sakit yaitu: 1) Keselamatan pasien (patient safety), yang meliputi angka kejadian infeksi nosokomial, kejadian pasien jatuh/ kecelakaan, dekubitus, kesalahan dalam pemberian obat, 2) Pengelolaan nyeri dan kenyamanan, 3) Tingkat kepuasan pasien terhadap pelayanan, 4) Perawatan diri, 5) kecemasan pasien, 6) Perilaku (pengetahuan, sikap, keterampilan ) pasien (Nursalam, 2011).

Strategi peningkatan mutu pelayanan keperawatan antara lain pendidikan berlanjut, sumber daya dimanfaatkan secara efesien dan efektif, aman bagi pasien dan provider, memuaskan bagi pasien dan provider, serta menghormati aspek sosial ekonomi, budaya, agama, etika, dan tata nilai masyarakat. Prasyarat peningkatan mutu pelayanan keperawatan antara lain pimpinan yang peduli dan mendukung, sadar mutu bagi seluruh staf, program diklat untuk meningkatkan sumber daya manusia, sarana dan lingkungan yang mendukung dan adanya standar (Depkes RI, 2015).

Penilaian item 8 sebagian besar $(43,9 \%)$ yang menilai baik disebabkan oleh perawat memahami bahwa peran perawat sebenarnya adalah membantu memenuhi kebutuhan dasar manusia seperti membantu mobilitas, eliminasi, ganti posisi dan lainlain. Menurut Wincof dalam Tjiptono (2014) kualitas pelayanan adalah tingkat keunggulan yang diharapkan untuk memenuhi keinginan pelanggandan pengendalian atas tingkat keunggulan tersebut.Sedangkan menurut Kotler, Keller (2016) kualitas layanan adalah totalitas fitur dan karakteristik produk atau jasa yang mampu memuaskan kebutuhan pelanggan yang dinyatakan atau tersirat.

Dalam pengukuran mutu pelayanan, menurut Kotler (2016) harus bermula dari mengenali kebutuhan pelanggan dan berakhir pada persepsi pelanggan. Hal ini berarti bahwa gambaran kualitas pelayanan harus mengacu pada pandangan pelanggan dan bukan pada penyedia jasa, karena pelanggan mengkonsumsi dan memakai jasa.

Penilaian item 9 sebagian besar $(57,6 \%)$ yang menilai baik disebabkan oleh perawat memahami medication error dapat terjadi dimana saja dalam rantai pelayanan obat kepada pasien, mulai dari apotik, dalam peresepan, pembacaan resep, peracikan, penyerahan, dan monitoring pasien. Berdasarkan kinerja mutu pelayanan keperawatan klinik tahun 2013 menurut Standar Pelayanan Minimum (SPM) diruang rawat inap yaitu pemberian pelayanan diruang rawat inap adalah dokter spesialis dan perawat dengan pendidikan minimal adalah D3 Keperawatan, penanggung jawab pasien adalah dokter, ketersediaan pelayanan rawat inap yaitu ruang anak, penyakit dalam, kebidanan, bedah, dan ICU. Jam visite dokter setiap hari kerja, kejadian infeksi luka operasi, infeksi nasokomial, dan kejadian pasien jatuh0 \%. Angka infeksi jarum infus sebanyak $2,62 \%(\leq 1,5 \%)$, angka infeksi transfusi sebanyak $0,62 \%(\leq 0,01 \%)$, angka kematian bayi < 2000 gr sebanyak 14,3\% (100\%), waktu tunggu operasi > 24 jam sebanyak 2,09 $\%$, meninggal karena sepsis sebanyak $0,64 \%(\leq 0,2 \%)$, compliance rekam medic sebanyak 0,92\% (100\%), kepuasan pasien terhadap mutu pelayanan rawat inap adalah $80 \%$ ( $\geq 90 \%$ ). Didalam setiap mata rantai ada beberapa tindakan, setiap tindakan mempunyai potensi sebagai sumber kesalahan. Setiap tenaga kesehatan dalam mata rantai pemberian obat dapat memberikan kontribusi terhadap kesalahan. Perawat berkolaborasi dengan dokter dalam pemberian obat kepada pasien, dalam memperoleh obat perawat harus membantu pasien dengan memberikan petunjuk dimana obat bisa diperoleh, membawa resep yang benar dan melaporkan kepada perawat jika obat habis dan lain-lain (Nursalam, 2014).

Penilaian item 10 sebagian besar $(43,9 \%)$ menilai kurang baik disebabkan perawat memahami dalam pemberian obat kepada pasien harus diawasi. Dalam pemberian obat perawat pun harus teliti dan selalu berkomunikasi dengan pasien. 
perawat harus cepat tanggap dalam memberikan obat pasien yang paling sering dikeluhkan pasien adalah saat cairan infuse habis perawat kurang tanggap sehingga keluarga pasienlah yang melaporkan, padahal perawat harus mempunyai catatan kapan cairan infuse harus habis dan harus diganti. Penilaian item 11 sebagian besar $(48,5 \%)$ menilai baik, ini disebabkan dalam pelayanan di ruang rawat inap biasanya perawat mengantarkan pasien untuk foto rongen dan laboratoriumn. namun kadang-kadang perawat meminta bantuan keluarga pasien untuk meminta hasil foto rongen, mengantar atau menjemput hasil labor, sebaiknya dirumah sakit ada petugas khusus untuk pelayanan medik tersebut seperti petugas labor datang ke ruangan untuk mengambil spesiemen dan mengantar hasil pemeriksaannya ke ruangan.

Menurut peneliti penilaian baik ini harus dapat dipertahankan, karena jika penilaian buruk akan berakibat terhadap menurunnya loyalitas pasien, seperti yang dikemukakan oleh Hasan (2014) sistem dan proses yang buruk sangat mempengaruhi penilaian pasien meskipun rumah sakit memiliki pegawai-pegawai yang terampil, seperti waktu tunggu yang lama adalah hal yang dapat menyebabkan rumah sakit kehilangan pelanggan.

Menurut peneliti responsiveness yaitu suatu kemauan untuk membantu dan memberikan pelayanan yang cepat (responsif) dan tepat kepada pasien dengan penyampaian informasi yang jelas. Membiarkan pasien menunggu tanpa adanya alasan yang jelas menyebabkan persepsi yang negatif dalam kualitas pelayanan keperawatan. Unsur yang paling penting dalam dimensi responsiveness ini adalah perawat selalu siap membantu pasiennya. Apa pun posisi seseorang di rumah sakit hendaknya selalu memperhatikan pasien. Menurut Watzlawick, Bavelas \& Jackson (2011) menjelaskan ketikaorang berinteraksi satu dengan yang lain, mereka mengirim pesan tertentu, sehubungan dengan proses interpersonal ini, ada tiga dimensi yang harus diperhatikan: komunikasi, pengambilan keputusan yang berorientasi pada pasien, dan perilaku interpersonal.

Penilaian baik ini harus dapat dipertahankan, karena jika penilaian buruk akan berakibat terhadap menurunnya loyalitas pasien, seperti yang dikemukakan Hasan (2014) sistem dan proses yang buruk sangat mempengaruhi penilaian pasien meskipun rumah sakit memiliki pegawai-pegawai yang terampil, seperti waktu tunggu yang lama adalah hal yang dapat menyebabkan rumah sakit kehilangan pelanggan.

Hasil penelitian ini didukung oleh penelitian Ulfa (2012) juga menunjukkan bahwa responden yang menilai dimensi responsiveness baik akan lebih loyal. Hasil penelitian Supartiningsih (2017) juga didapatkan bahwa dimensi responsiveness berpengaruh terhadap tingkat loyalitas pasien. Ketanggapan (responsiveness) mempunyai pengaruh positif dan signifikan terhadap tingkat loyalitas pasien rumah sakit umum di kota Singaraja-Bali. Penelitian Suharno dan Sihap (2012) juga mendukung penelitian ini bahwa terdapat hubungan antara ketanggapan dengan loyalitas pasien.

\section{SIMPULAN}

Responden terbanyak berasal dari kelompok umur dewasa awal, jenis kelamin perempuan, berpendidikan tinggi, bekerja, jarak tempat tinggal jauh dari rumah sakit, menggunakan asuransi, dan belum pernah dirawat sebelumnya. Sikap loyalitas pasien di ruang rawat inap RSUD Kota Tanjungpinang tergolong sebagian besar baik Persepsi responden terhadap kualitas pelayanan keperawatan di rawat inap RSUD Kota Tanjungpinang tergolong baik. Sementara persepsi responden terhadap dimensi 
reliability dan responsiveness di ruang rawat inap RSUD Kota Tanjungpinang tergolong baik.

Persepsi responden tentang reliability dan esponsiveness berhubungan secara signifikan dengan loyalitas pasien. Dimensi kualitas pelayanan keperawatan yang paling dominan berhubungan dengan loyalitas pasien adalah dimensi responsiveness

\section{SARAN}

Bagi Manajemen Keperawatan di RSUD Kota Tanjungpinang

1. Untuk menjaga sikap loyalitas responden yang sudah baik, perlu dilakukan upaya peningkatan kualitas layanan secara terus menerus terutama dalam dimensi responsiveness terhadap pasien yang dinilai memiliki pengaruh paling besar dalam aspek kualitas layanan terhadap loyalitas pasien dalam penelitian ini.

2. Aspek dari kualitas pelayanan keperawatan yang perlu ditingkatkan adalah pemahaman perawat tentang manajemen mutu serta aplikasi dalam manejemen ruangan dalam rangka mengelola pelayanan keperawatan beserta ruang rawat yang berorientasi pada kebutuhan pasien, dengan metode penugasan yang efektif maka kebutuhan pasien akan lebih terpenuhi.

3. Melakukan evaluasi secara berkala mengenai kualitas pelayanan keperawatan dan melakukan sistem keluhan dan saran dengan customer care secara rutin dengan memberikan kesempatan seluas luasnya pada pasien untuk memberikan saran, pendapat dan keluhan. Media yang dapat digunakan meliputi kotak saran dengan menyedikan kartu komentar yang dapat diisi langsung.

Penelitian ini digunakan sebagai dasar penelitian berikutnya dengan menggunakan variabele lain yang berhubungan dengan loyalitas pasien seperti kepuasan pasien, hambatan pindah, citra rumah sakit dan-lain sebagainya. Pengumpulan data dapat lebih dikembangkan dengan menggunakan kuesioner dan wawancara mendalam serta dengan rancangan penelitian yang berbeda agar data atau informasi yang didapatkan dapat lebih akurat dan mendalam.

\section{DAFTAR PUSTAKA}

Ahira, A. (2012) Rumah Sakit-Sejarah dan Jenis-jenis Rumah Sakit. http://www.anneahira.com/rumah-sakit-20850.htm

Asmuji .(2012). Manajeman Keperawatan: Konsep dan Aplikasi. Yogyakarta,Ar- Ruzz Media

Baroroh. (2010). Hubungan antara Persepsi terhadap Kualitas Pelayanan dan Citra Rumah Sakit dengan Loyalitas Pasien di Rumah Sakit Roemani Muhammadiyah Semarang

Dahlan, M. S. (2009). Statistik untuk Kedokteran dan Kesehatan: Deskriptif, Bivariat, dan Multivariat, Dilengkapi dengan Menggunakan SPSS. Jakarta: Salemba Medika

Depkes RI. (2007). Riset Kesehatan Dasar (RISKESDAS) Nasional Tahun 2007. http://www.litbang.depkes.go.id/

Dharma, K.K. (2011). Metode Penelitian Keperawatan: Panduan Melaksanakan dan Menerapkan Hasil Penelitian. Jakarta: TIM

Dharmestha, S \& Hani H. (2008). Manajemen Pemasaran: Analisa Perilaku Konsumen, Edisi Pertama. Cetakan Keempat. BPFE. Yogyakarta

Griffin, J. (2016). Customer Loyalty: Menumbuhkan \& Mempertahankan Kesetiaan Pelanggan. Jakarta: Penerbit Erlangga 
Gunawan, K. (2009). Kualitas Layanan dan Loyalitas Pasien (Studi pada Rumah Sakit Umum Swasta di Kota Singaraja-Bali). Jurnal ekonomi

Gunawan. A. ( 2013). Komunikasi Interpersonal dan Fasilitas Kesehatan: Pengaruhnya terhadap Kepercayaan, Loyalitas dan WOM Rumah Sakit. Jurnal bisnis manajemen

Haryono, E, Hari, K. \& M. Syafril, N. (2006). Hubungan Persepsi terhadap Kualitas Pelayanan dengan Minat Pemanfaatan Pelayanan Rawat Inap Puskesmas dan Balai Pengobatan Swasta di Kabupaten Tapanuli Tengah. Working Paper Series No.4. Universitas Gadjah Mada

Hasan, A. (2014). Marketing, Cetakan Pertama. Yogyakarta: Buku Kita

Imbalo, S. P. (2012). Jaminan Mutu Layanan Kesehatan. Cetakan I. Jakarta: EGC

Jane. (2011). How Satisfaction Modifies the Strength of the Influence of Perceived Service Quality on Behavioral Intentions. Journal Leadership in Health Services, 24(2), 91-105

Kotler,P., \& Keller,L. (2016). Manajemen Pemasaran. Jakarta: Prenhalindo

Lupiyoadi, R \& Hamdani, A. (2013). Manajemen Pemasaran. Jakarta: Salemba Empat

M.Zid. (2013). Berobat Keluar Negeri Tetap Trend. Kliping Pusat Komunikasi Setjen Kementerian Kesehatan RI. Jakarta: Kompas 7 Maret 2013 edisi pagi hal : 13

Mabow. (2009). Minat Pembeli Dalam Psikologi

Mardalis. A. (2015). Meraih Loyalitas Pelanggan. Jakarta: Balai Pustaka

Marquis, B.L. \& Huston, C.J. (2010). Kepemimpinan dan Manajemen Keperawatan: Teori dan Aplikasi. Edisi Keempat. Jakarta: EGC

Munijaya, I. G. ( 2012). Manajemen Kesehatan. Jakarta: Penerbit Buku Kedokteran, EGC

Nursalam. (2014). Manajemen Keperawatan.Edisi 4. Jakarta: Salemba Medika

Profil Rumah Sakit Umum Daerah Kota Tanjungpinang Tahun 2013

Putri dan Heru (2014). Faktor-Faktor yang Berhubungan dengan Kepuasan Pasien Rawat Inap di RSAM Bukittinggi

Rahmani, A. (2018). Jurnal Faktor Kepuasan Pelanggan untuk Mengembangkan Bisnis

Riset Kesehatan Dasar. (2013). Badan Penelitian dan Pengembangan Kesehatan Kementerian RI tahun 2013., dari http:// www.depkes.go.id/resources/download/general/Hasil\%20Riskesdas\%202013.pdf Diakses: 19 Oktober 2017

Sangadji, E. M \& Sopiah. (2013). Perilaku Konsumen Pendekatan Praktis. Yogyakarta: Andi

Setiawan, S. (2011). Loyalitas Pelanggan Jasa. Bogor: IPB Press

Stewart, A. L. (2013). Making Sense of Entrepreneurship Journals: Journal Rankings and Strategy Choices

Suhanura, A. (2008). Analisis Loyalitas Pelanggan Poli Kebidanan dan Kandungan Rumah Sakit Asri, Thesis. FKM UI

Suharno.M. \& Shihab.(2012). Pengaruh Dimensi Reliabilitas, Dimensi Tangibel dan Dimensi Empati terhadap Loyalitas Pasien (Studi Kasus: Pasien Rawat Jalan RS MRCCC Siloam Semanggi). Jurnal Manajemen dan Bisnis Sriwijaya, 10(19) Juni 2012

Supartiningsih, S. (2017). Kualitas Pelayanan Kepuasan Pasien Rumah Sakit: Kasus pada Rawat Jalan. Jurnal Medicoeticolegal dan manajemen $R S$, 6(1), 9-15, Jan 2017 
Supriyanto, S \& Ernawaty. (2010). Pemasaran Industri Jasa Kesehatan. Yogyakarta: Andi

Tjiptono, F. (2014). Prinsip-Prinsip Total Quality Service. Yogyakarta: Andi

Trarintya, M. A. P. (2011). Pengaruh Kualitas Pelayanan terhadap Kepuasan dan Word of Mouth (Studi Kasus Pasien Rawat Jalan di Wing Amertarsup Sanglah Denpasar ). TESIS Program Pasca Sarjana Universitas Udayana Denpasar. (Tidak dipublikasikan)

Tri. W. (2017). Faktor-Faktor yang Berhubungan dengan Kepuasan Pasien BPJS di Puskesmas Pemalang

Ulfa, R. (2012). Hubungan Karakteristik Pasien, Kualitas Layanan dan Hambatan Pindah dengan Loyalitas Pasien di Instalasi Rawat Jalan Rumah Sakit Tugu ibu Depok. (tidak dipublikasikan)

Watzlawick, P., Bavelas, J.B \& Jackson, D.D. (2011). Pragmatics of Human Communication: A study of Interactional Patterns, Pathologies, and Paradoxes; jurnal of W.W. Norton \& Company

Wloszczak, S, Anna, M.J. Jarost \& Goniewicz, M. (2013). Professional Communication Competences of Paramedicspractical and Educational Perspectives. Annals of Agricultural and Environmental Medicine, 2(2), 366-372

Zolnierek, K.B.H. \& Dimatteo, M. R. (2009). Physician Communication and Patient Adherence to Treatment: A Metaanalysis. Medical Care, 47(8), 826-834 